原著

\title{
脳卒中外科における術中モニタリングの役割
}

\author{
佐々木達也 ${ }^{1}$, 昆 博之 ${ }^{1}$, 斉藤 敦志 ${ }^{1}$, 中村 太源 ${ }^{1}$, 針生 新也 ${ }^{1}$

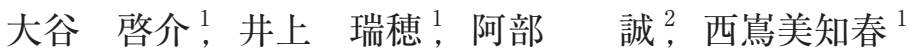

\section{Role of Intraoperative Monitoring in Cerebrovascular Surgery}

\author{
Tatsuya SASAKI, M.D. ${ }^{1}$, Hiroyuki Kon, M.D. ${ }^{1}$, Atsushi SAITo, M.D. ${ }^{1}$, Taigen NAKAmura, M.D. ${ }^{1}$, \\ Shinya Haryu, M.D. ${ }^{1}$, Keisuke Ohtani, M.D. ${ }^{1}$, Mizuho Inoue, M.D. ${ }^{1}$, Makoto ABe, B.S. ${ }^{2}$, and \\ Michiharu NishiJIMA, M.D. ${ }^{1}$ \\ ${ }^{1}$ Departments of Neurosurgery, and ${ }^{2}$ Medical Engineering, Aomori Prefectural Central Hospital, \\ Aomori, Japan
}

Summary: Object: Here, we evaluated the role of various methods of intraoperative monitoring in cerebrovascular surgery.

Materials and Methods: A total of 263 patients underwent cerebrovascular surgery using intraoperative monitoring after the introduction of a 16-channel Neuromaster. There were 229 cerebral aneurysm (85 ruptured, 144 unruptured), five arteriovenous malformation (AVM), 19 bypass, seven carotid endarterectomy (CEA), and three cavernous angiomas cases. Motor-evoked potential (MEP), somatosensory-evoked potential (SEP), and visual-evoked potential (VEP) were selected considering the pathogenesis types and sites. MEP contained transcranial and direct cortical stimulation and SEP, median nerve (upper extremity) and posterior tibial nerve (lower extremity) stimulation. Bilateral regional saturation of oxygen $\left(\mathrm{rSO}_{2}\right)$ using near-infrared spectroscopy (NIRS) was also monitored in patients who underwent CEA.

Results: Intraoperative monitoring was successfully performed in all 263 cases. MEP could not be recorded and an upper-extremity SEP was performed in three cases because of preexisting hemiparesis. In 15 cases, MEP disappeared after temporary occlusion of the parent artery or aneurysmal clipping but reappeared after release of the temporary occlusion or re-clipping; one patient whose MEP amplitude recovered to $50 \%$ of the control developed transient hemiparesis (4/5). Another two patients, in whom the MEP disappeared until the end of surgery, developed permanent hemiparesis (4/5). In a patient with a posterior cerebral artery (PCA) aneurysm, VEP was transiently decreased after temporary PCA occlusion. In a patient with the premotor AVM, the MEP was transiently decreased after the precentral artery was temporarily occluded. In a patient with an occipital cavernous angioma, the VEP transiently decreased after dissection around the posterior horn and the patient was discharged from the hospital without any visual field disturbances. Three patients with CEA in whom the transcranial MEP and upper extremity SEP decreased, recovered after insertion of the internal shunt.

Conclusions: In cerebrovascular surgery, various methods of monitoring enable us to detect intraoperative ischemia and feedback to the operative maneuvers.

\author{
Key words: \\ - cerebrovascular surgery \\ $\cdot$ intraoperative monitoring \\ $\cdot$ motor evoked potential \\ - somatosensory evoked \\ potential \\ - visual evoked potential
}

Surg Cereb Stroke

(Jpn) 43: 359-366, 2015

1青森県立中央病院 脳神経外科, ${ }^{2}$ 青森県立中央病院 臨床工学部(受稿日 2014. 11. 8) (脱稿日 2014. 2. 23)〔連絡先： † 030-8553 青森県 青森市東造道 2-1-1 青森県立中央病院 脳神経外科 佐々木達也] [Address correspondence: Tatsuya SASAKI, M.D., Department of Neurosurgery, Aomori Prefectural Central Hospital, 2-1-1 Higashitsukurimichi, Aomori, Aomori 030-8553, Japan] 


\section{はじめに}

脳卒中の外科治療としては, 脳動脈瘤クリッピング, 脳 動静脈奇形 (arteriovenous malformation: AVM) 摘出術, 虚血性疾患に対する浅側頭動脈 (superficial temporal artery：STA)-中大脳動脈 (middle cerebral artery：MCA) 吻合術, 澒動脈内膜剝離術 (carotid endarterectomy: CEA), 海綿状血管腫摘出術, 高血圧性脳内血腫除去術な どが挙げられる。これらの脳卒中外科治療における各種術 中モニタリングの現状について検討したので, 若干の考察 を加え報告する。

\section{対象と方法}

対象は, Neuromaster (16 Ch, 日本光電, 東京) を導入 した 2009 年 9 月から 2012 年 8 月までの 3 年間に, 術中モ ニタリング下に手術を施行した脳血管障害の 263 例であ る. 内訳は, 脳動脈瘤 229 例( 破裂 85 例, 未破裂 144 例 ), AVM 5 例, STA-MCA 吻 合術 19 例, CEA 7 例, 海綿状血管腫 3 例であった。 なお，高血圧性脳内血腫は術 前から片麻瘏を有している症例が多く，原則的に局所麻酔 下に内視鏡による血腫除去を施行しているため，モニタリ ングを施行した症例はなかった. 病変の種類, 部位により 適宜, 経頭蓋刺激運動誘発電位 (motor evoked potential : $\mathrm{MEP}$ ), 皮質刺激 MEP, 正中神経刺激(上肢)体性感覚誘 発電位 (somatosensory evoked potential：SEP), 後脛骨 神経刺激(下肢)SEP, 視覚誘発電位 (visual evoked potential：VEP) を施行した. CEA では近赤外線分光法(nearinfrared spectroscopy : NIRS, INVOS ${ }^{\mathrm{TM}}$ 5100C)を用いた 局所酸素飽和度 (regional saturation of oxygen : $\mathrm{rSO}_{2}$ ), のモニタリングも施行した。 モニタリング法の詳細に関し ては誌面の関係で割愛するので, これまでの報告を参照さ れたい(1)4)6-13).

モニタリングの種類の選択は, 脳動脈瘤症例では, 内澒 動脈瘤・中大脳動脈瘤の場合は両側の経頭蓋 MEP と患側 の皮質 MEP を, 前交通動脈瘤・前大脳動脈瘤の場合は両 下肢 SEP を, 後大脳動脈瘤や大型で視神経・視交叉を圧 迫するような動脈瘤ではVEPをモニタリングした。 STA-MCA 吻合術や CEA の症例では, 両側経頭蓋 MEP と患側の上肢 SEPをモニタリングし, CEA 症例では $\mathrm{rSO}_{2}$ のモニタリングを追加し, 両側の前額部でモニタリ ングした. AVM や海綿状血管腫の症例では, 病変の部位 により適宜モニタリングを選択した。

\section{結果}

263 例全例で術中モニタリングが可能であったが, 術前 から片麻痺を認めた 3 例では MEP が記録できず，上肢
SEP にてモニタリングした。

脳動脈瘤手術では，15 例で経頭蓋および皮質 MEP がほ ぼ同時に消失した。遮断の解除, clip のかけ直しにより, 13 例で経頭盍および皮質 MEP がほぼ同時に回復した. 13 例中 2 例では振幅の回復が不良で, 術後一過性の運動麻瘏 が出現した。 MEP が回復しなかった 2 例では, 術後に片 麻痺が後遺した.PCAの動脈瘤では, 親動脈一時遮断時 にVEPの一過性の低下を認めた.

AVM では premotor AVM の 1 例で, 運動領野の mapping と precentral artery の確認・温存に MEP が有用で あった(Case 1).

STA-MCA 吻合術を施行した症例では, もやもや病症 例を含めて術中に MEP や上肢 SEP が悪化した症例はな く，術後にも神経症状が増悪した症例はなかった。

CEA では, 7 例中 3 例で血流遮断時に患側の経頭蓋 MEP の消失, 上肢 SEP の振幅低下を認め, 内シャントの 挿入により回復した (Case 2). 残る 4 例では, MEP およ び上肢 SEP に遮断中にまったく変化を認めず，シャント は不要と判断し使用しなかった. 術後に虚血性の症状を呈 した症例や hyperperfusion を呈した症例はなかった。

海綿状血管腫では, 術前から MMT 4/5の片麻痺を呈し ていた運動領野の海綿状血管腫の症例で皮質 MEP が記録 できず，上肢 SEP のみで運動領野の mapping とモニタリ ングを施行し, 術後に運動麻㾇の増悪はなかった. 後頭葉 海綿状血管腫の症例では, VEP の一過性の低下を認めた が，視野障害なく退院した(Case 3).

全体で経頭蓋 MEP モニタリングが可能であった 248 例 における術中 MEP 所見と術後片麻痺との相関を Fig. 1 に 示す. MEPに変化がないか, 変化があっても回復すれ ば, 術後運動麻痺は軽度で一過性であった. MEP が消失 したまま手術を終了した 2 例は前述したごとく運動麻痺が 後遺したが，その程度は幸い軽度であった。

以下に代表症例を提示する。

\section{症例}

\section{$\langle$ Case 1〉}

25 歳, 男性. 突然の運動性失語にて発症した。運動麻 痺は認めなかった。CT および MRI では左前運動領野に 脳内血腫を認め, その後方に nidus を認めた(Fig. 2). 手 術は左前頭開頭で, 硬膜切開後に上肢 SEP の N20 の逆転 と皮質 MEP を用い運動領野を mapping した. nidusは前 運動領野に存在しているものと思われた。そのまま皮質 MEP をモニタリングしながら手術操作を進めた。術野の nidus 後方の動脈を遮断すると 2 分で皮質 MEP が消失 し, 遮断の解除によりすぐに回復した.この動脈は precentral artery と考えられ, nidusに向かう細い枝のみを 


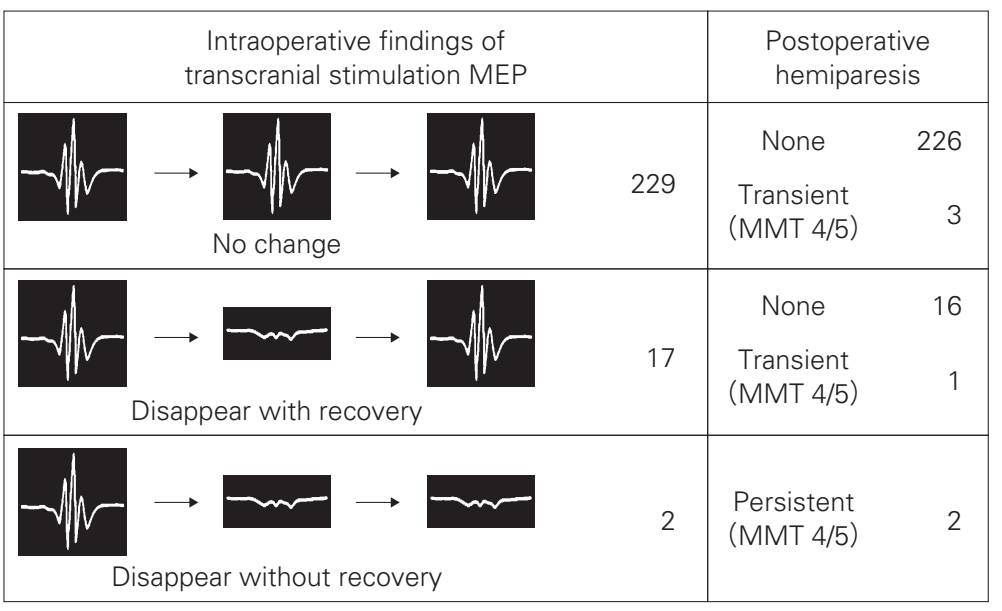

Fig. 1 Correlation between transcranial stimulation motor-evoked potential and postoperative hemiparesis.
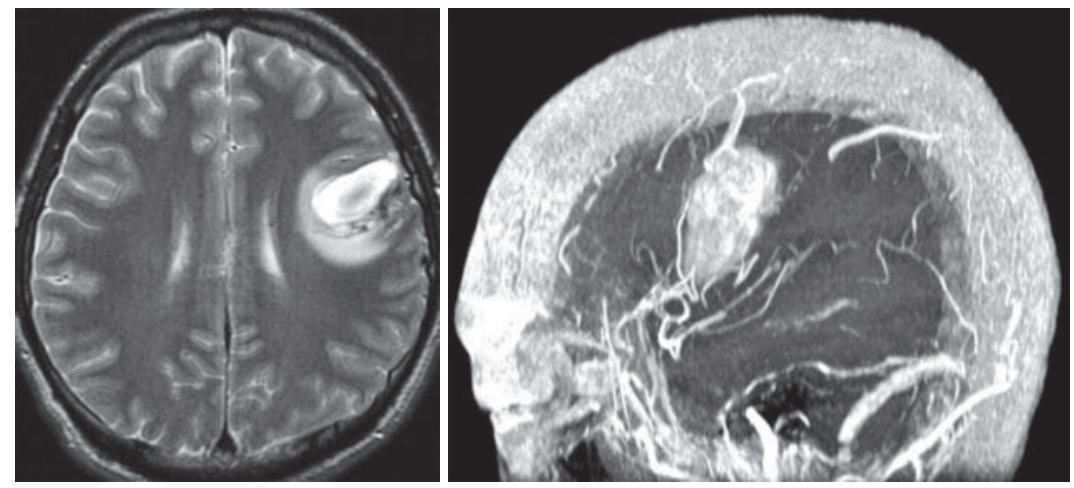

Fig. 2 A: Magnetic resonance image showing the nidus behind the hematoma.

B: Three dynamic computed tomography angiography showing the correlation among the nidus, feeder, and drainer.

C, D: Angiography showing that the nidus exists in the premotor area and that the drainer exists anteriorly.
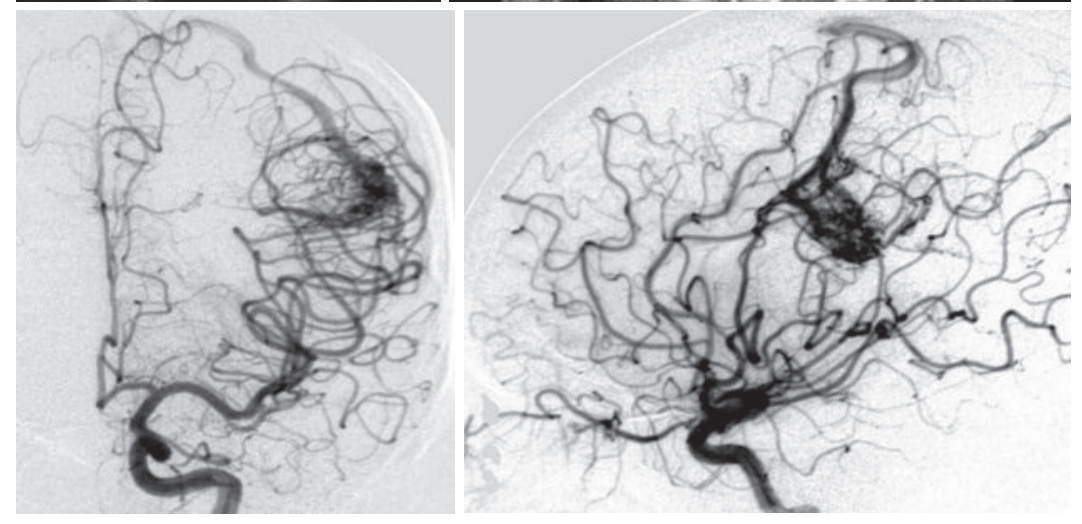

処置し, 本幹は passing artery として温存することとし た，術野の上方から流入する precentral arteryよりも前 方の feeder は, 遮断しても皮質MEPに変化を認めな かった。これらの 3 本は nidus ぎりぎりまで辿った後に凝 固切断し, nidusを一塊として摘出した(Fig. 3). 皮質 MEP に変化を認めず, 術後片麻疩の出現もなく, 脳血管 撮影では nidus は消失し precentral artery は温存されて いた(Fig. 4). $\langle$ Case 2〉

64 歳, 男性. 閉塞性動脈硬化症の精査で右澒部内頝動 脈閉塞と左頚部内頝動脈の $70 \%$ の狭窄を認めた (Fig. 5). 前交通動脈による cross flow はあるが，対側が閉塞のため 逆行性であった。頚部内頝動脈の遮断により $\mathrm{rSO}_{2}$ は約 $28 \%$ 低下し, MEP は遮断後 6 分で消失し, SEP は約 $50 \%$ の振幅低下を認めた(Fig. 6)。ただちに内シャントを挿入 し, $\mathrm{rSO}_{2}$ は約 $15 \%$ の低下まで改善し， MEP， SEP の振幅 も回復した。内シャント抜去時に再度 $\mathrm{rSO}_{2}$ の低下, MEP の消失，SEPの振幅低下を認めたが，遮断解除によりす 

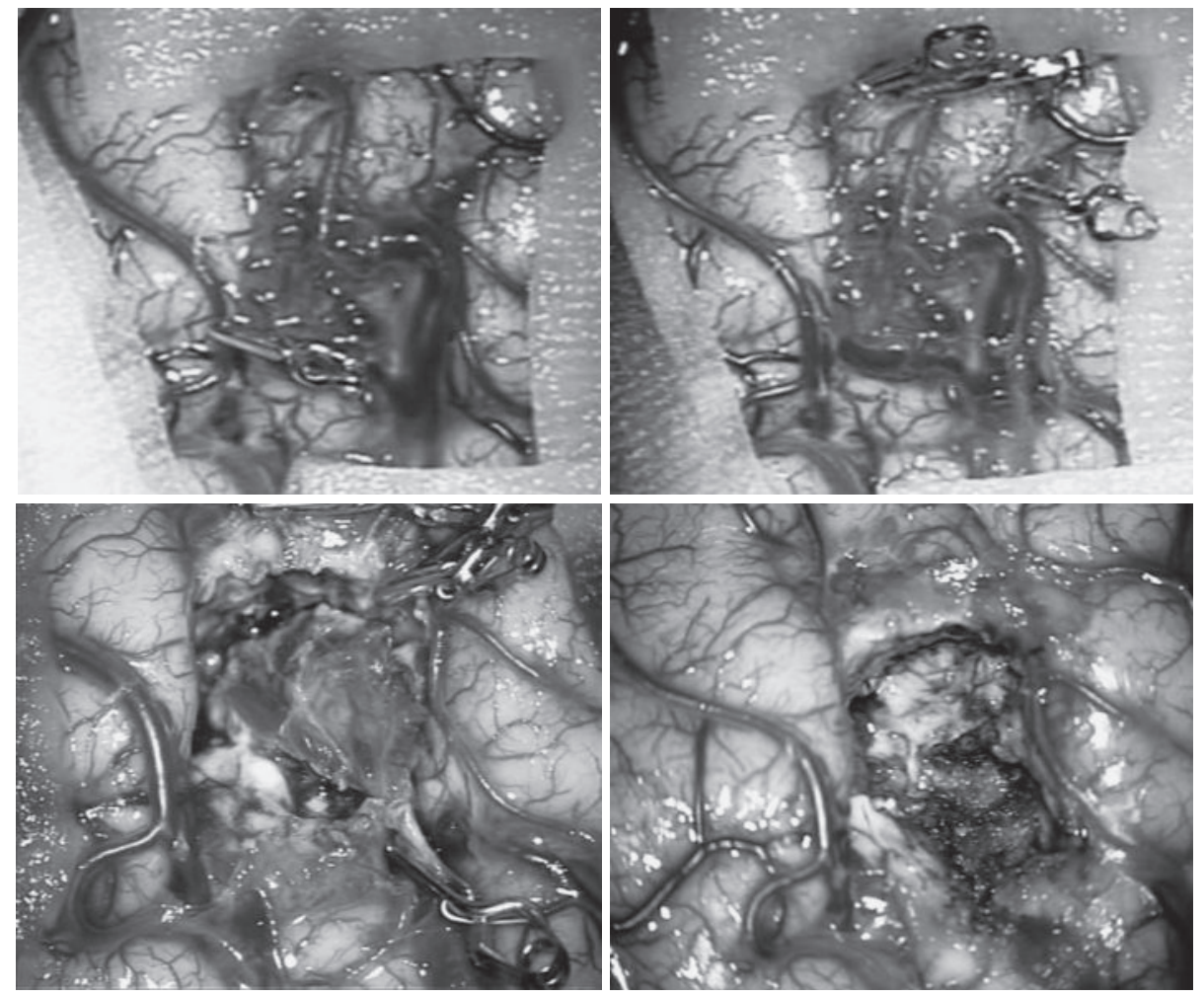

\section{\begin{tabular}{l|l} 
A & B \\
\hline C & D
\end{tabular}}

Fig. 3 A: Two minutes after occlusion of the precentral artery, the cortical motor-evoked potential (MEP) disappeared. B: After occlusion of the three feeders, the MEP remained unchanged.

C: The drainer was occluded.

D: The nidus was removed.
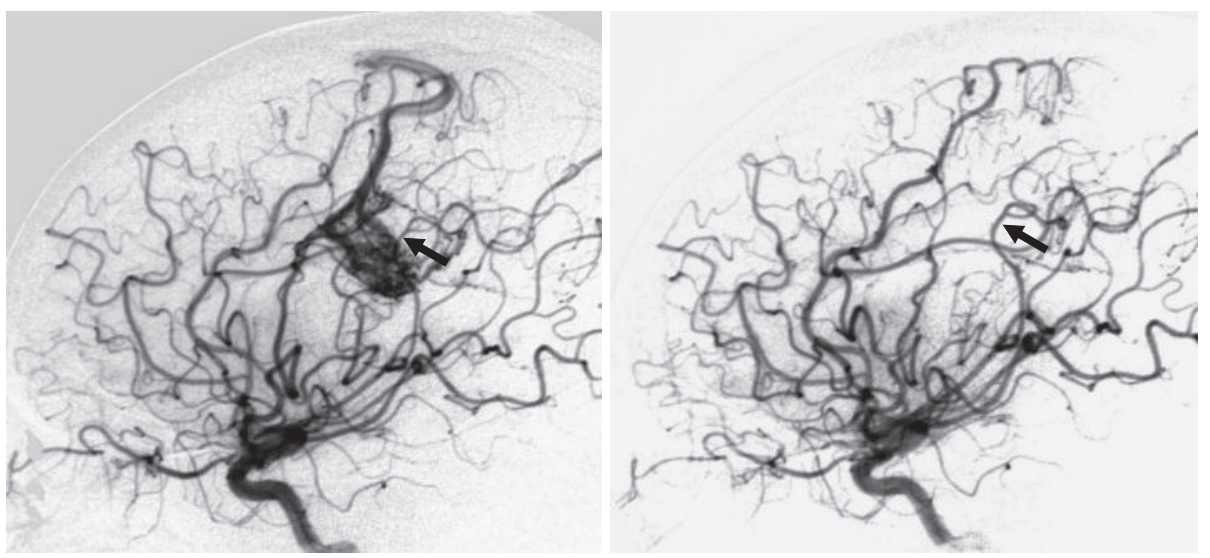

Fig. 4 Postoperative angiography showing disappearance of the nidus and preservation of the precentral artery.

ベて回復した．経過中，対側の MEP に変化を認めなかっ た，術後虚血症状を認めず退院した。

\section{$\langle\text { Case } 3\rangle^{3)}$}

15 歳, 女児. 意識消失発作と全身けいれん発作をきた し，手術目的に紹介された，頭部 CT および MRIでは右 後頭葉に血腫と海綿状血管腫を認めた (Fig. 7)。術前に視 野障害は認めなかった。VEP モニタリング下に摘出術を 施行した。記録電極は, 左側ではInion の $4 \mathrm{~cm}$ 上方, $4 \mathrm{~cm}$ 外側の部に針電極を頭皮に刺入し，右側では皮質切 開の予定線を挟んで銀ボール電極を皮質上に設置した
(Fig. 8). 右後頭葉に皮質切開をおいて血腫腔に入り, 海 綿状血管腫と脳実質の間の剝離を進めた。これらの操作中 VEP 波形には変化がなかったが, 最後に側脳室近傍を剝 離している際にVEP の振幅が低下したため手術操作を一 時中断した、VEPが回復した時点で血管腫を一塊として 摘出した(Fig. 9). 病理診断は海綿状血管腫で, CT およ びMRIでは，血管腫は完全に摘出されていた，術後，両 眼とも視野異常は認めず，神経脱落症状なく退院した

(Fig. 10). 


\section{考察}

脳卒中の外科治療としては, 脳動脈瘤クリッピング, AVM 摘出術，もやもや病などの虚血性疾患に対する STA-MCA 吻合術, CEA, 海綿状血管腫摘出術などが挙 げられる，疾患ごとにモニタリング法を選択する必要があ るが，AVM や海綿状血管腫では病変の存在部位によりモ ニタリング法を選択することになる，本稿では，各種のモ ニタリング法ごとにその適応と役割について考察する.

まず，MEPの適応であるが，脳動脈瘤では内頚動脈 瘤・中大脳動脈瘤がよい適応となる ${ }^{213)}$ 。最近では, 刺激 強度の工夫により経頭蓋 MEP の有用性も報告されてきて いる ${ }^{112)}$ ，AVM や海綿状血管腫では，運動領野や基底核

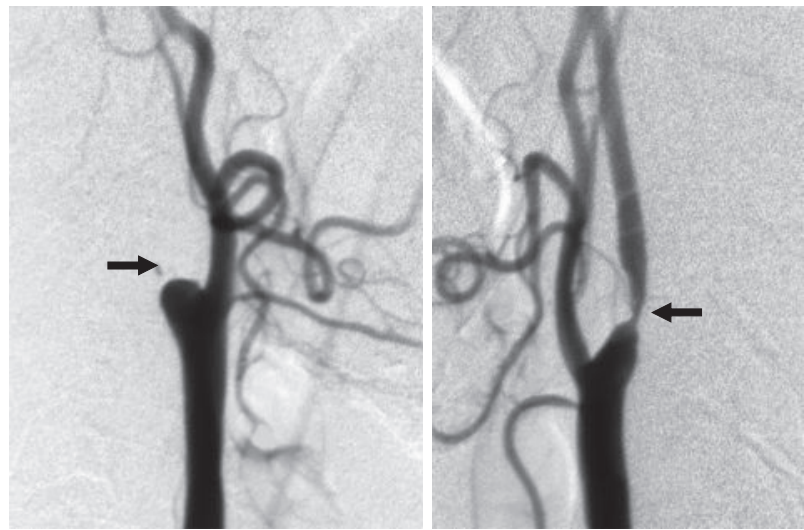

Fig. 5 Angiography showing occlusion of the right internal carotid artery (ICA; left arrow) and severe (70\%) stenosis of the left ICA (right arrow).
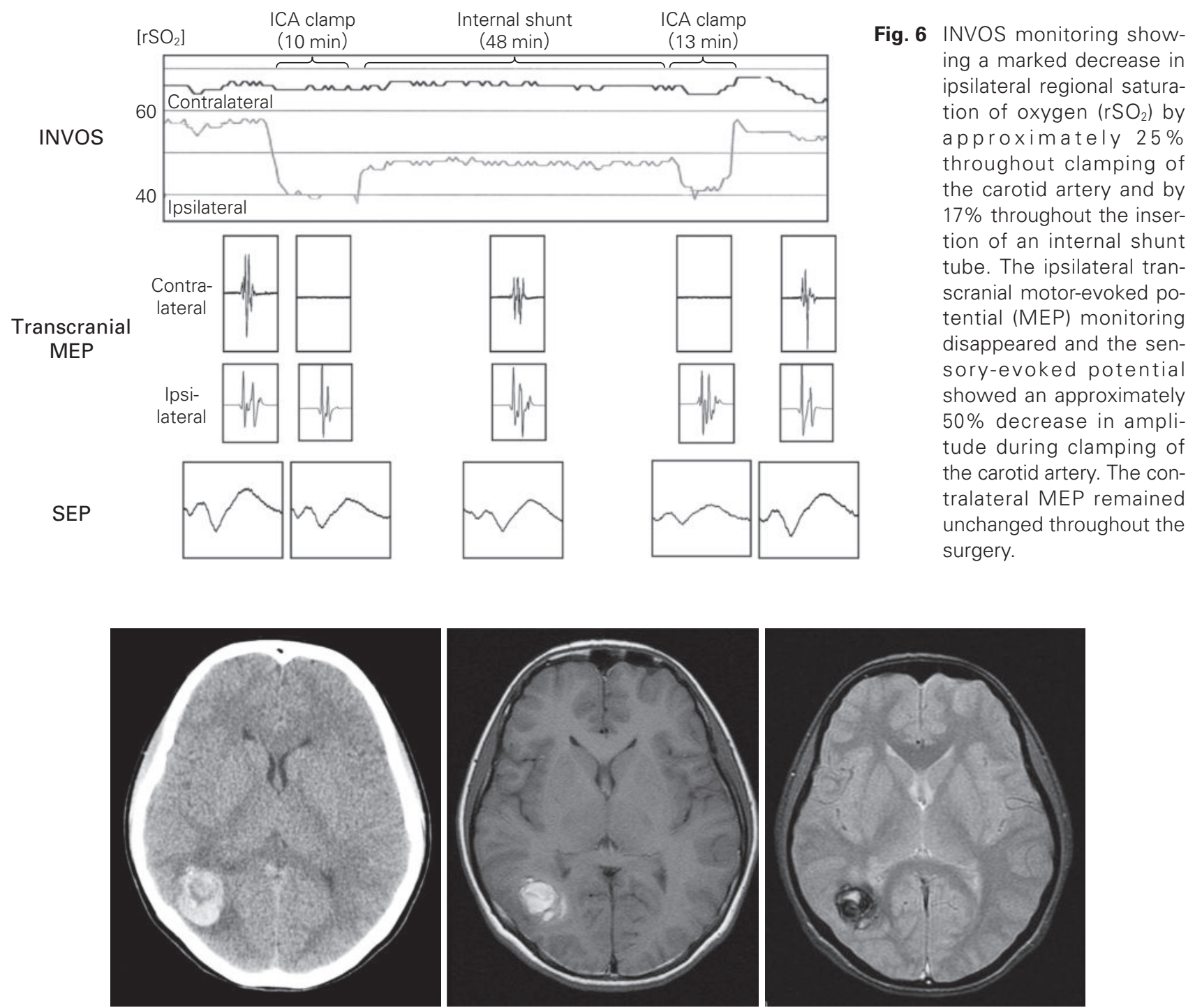

Fig. 7 Computed tomography scan and magnetic resonance image (T1WI and T2*) shoWing a hematoma and cavernous angioma in the right occipital lobe. 

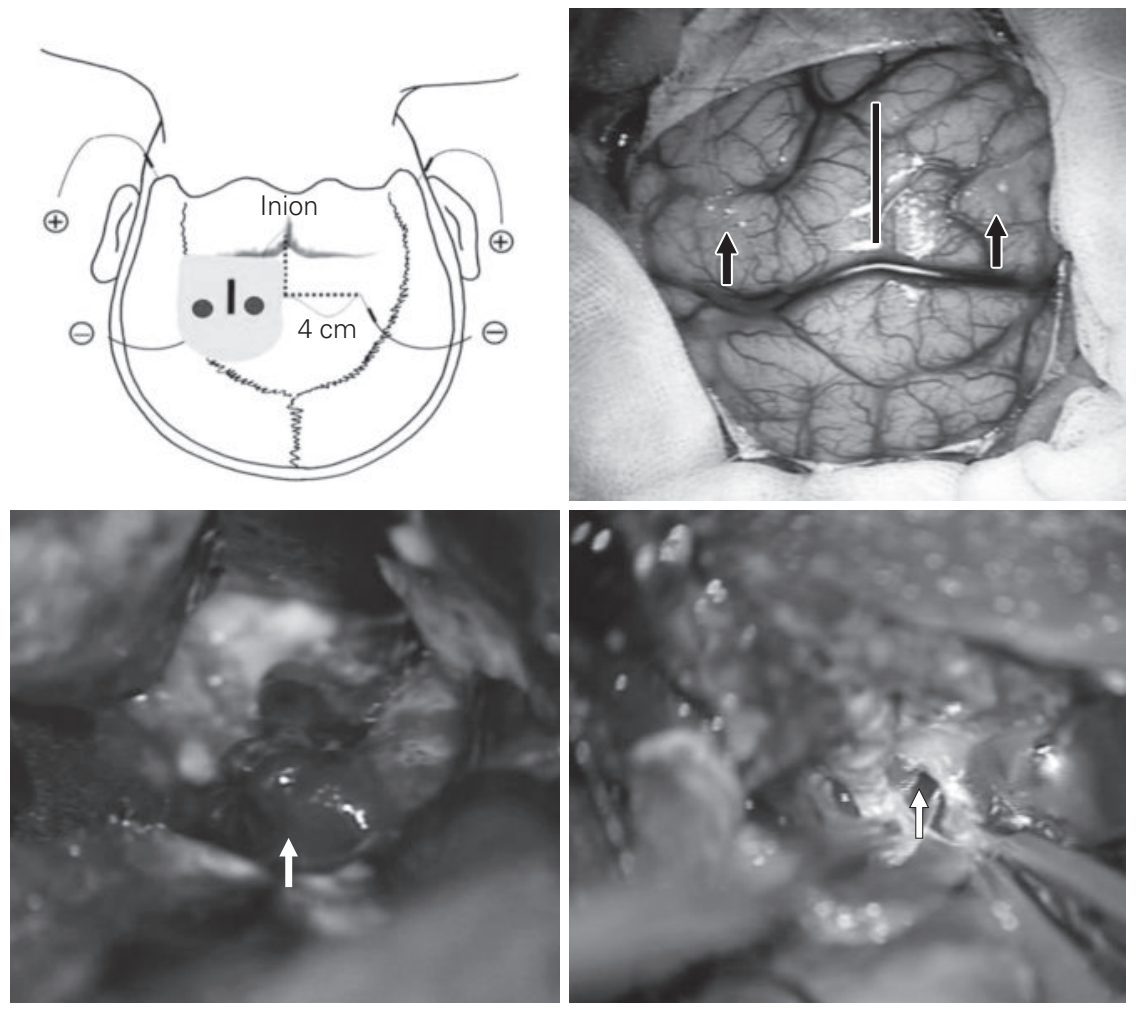

Fig. 8 A: Schematic drawing of the setting of the electrodes.

B: Two silver ball electrodes were placed on the occipital lobe.

C: The angioma was dissected from the surrounding tissue.

D: The angioma was removed. Part of the posterior horn of the right lateral ventricle was observed.

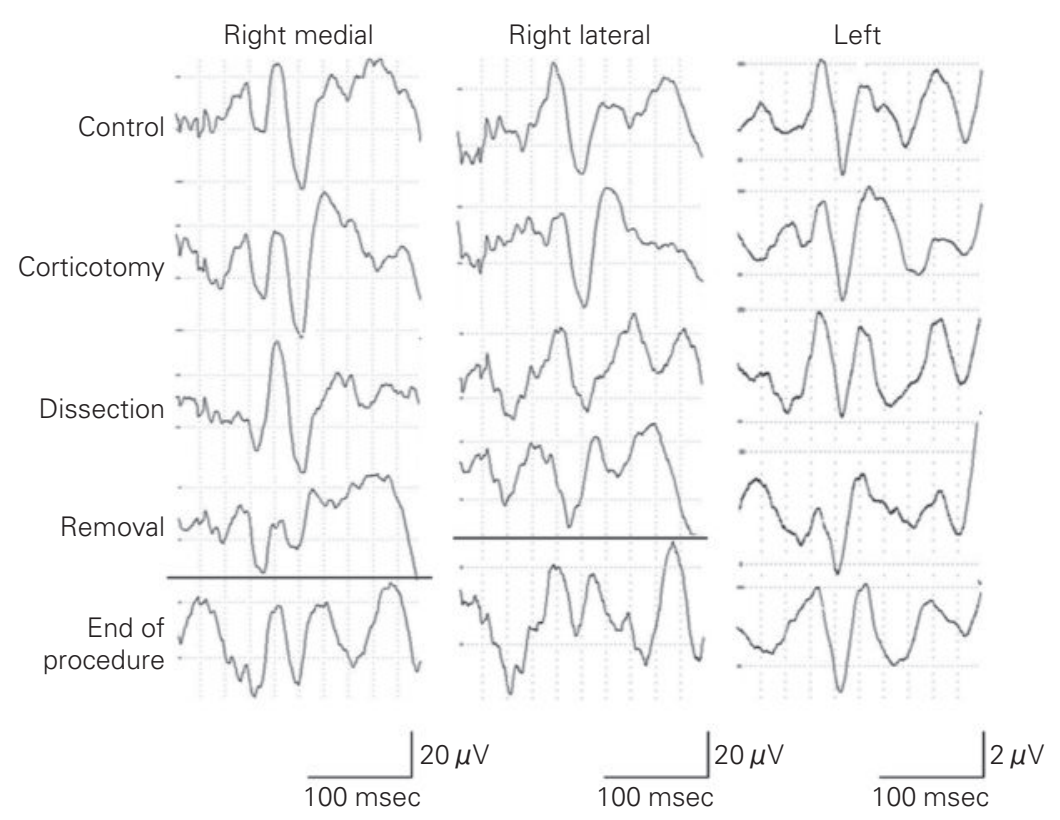

Fig. 9 Intraoperative VEP findings. The amplitudes of the right recording were decreased when the angioma was dissected near the posterior horn of the right lateral ventricle.
のものがよい適応になる，特に運動領野の病変では, 後述 する上肢 SEP の N20 の逆転7) と併用して運動領野を同定 する際に有用である。また， STA-MCA 吻合術や CEA で は, 血流遮断時の虚血や術中の低血圧による脳梗塞出現の 防止に有用と思われる。 MEPによって血流不全を同定で きるのは, 前脈絡叢動脈, レンズ核線条体動脈，中大脳動
脈などの動脈の中で皮質脊髄路を灌流している動脈であ り，それらの動脈でも皮質脊髄路を灌流していなければ MEP は変化しない，これまでの経験では，MEP に変化が なければ, 術後の運動麻疩は出現しても軽度で一過性であ り，MEPは術後運動麻疩の防止のために有用であった。 今回のシリーズで MEP が消失したまま手術を終了し, 運 


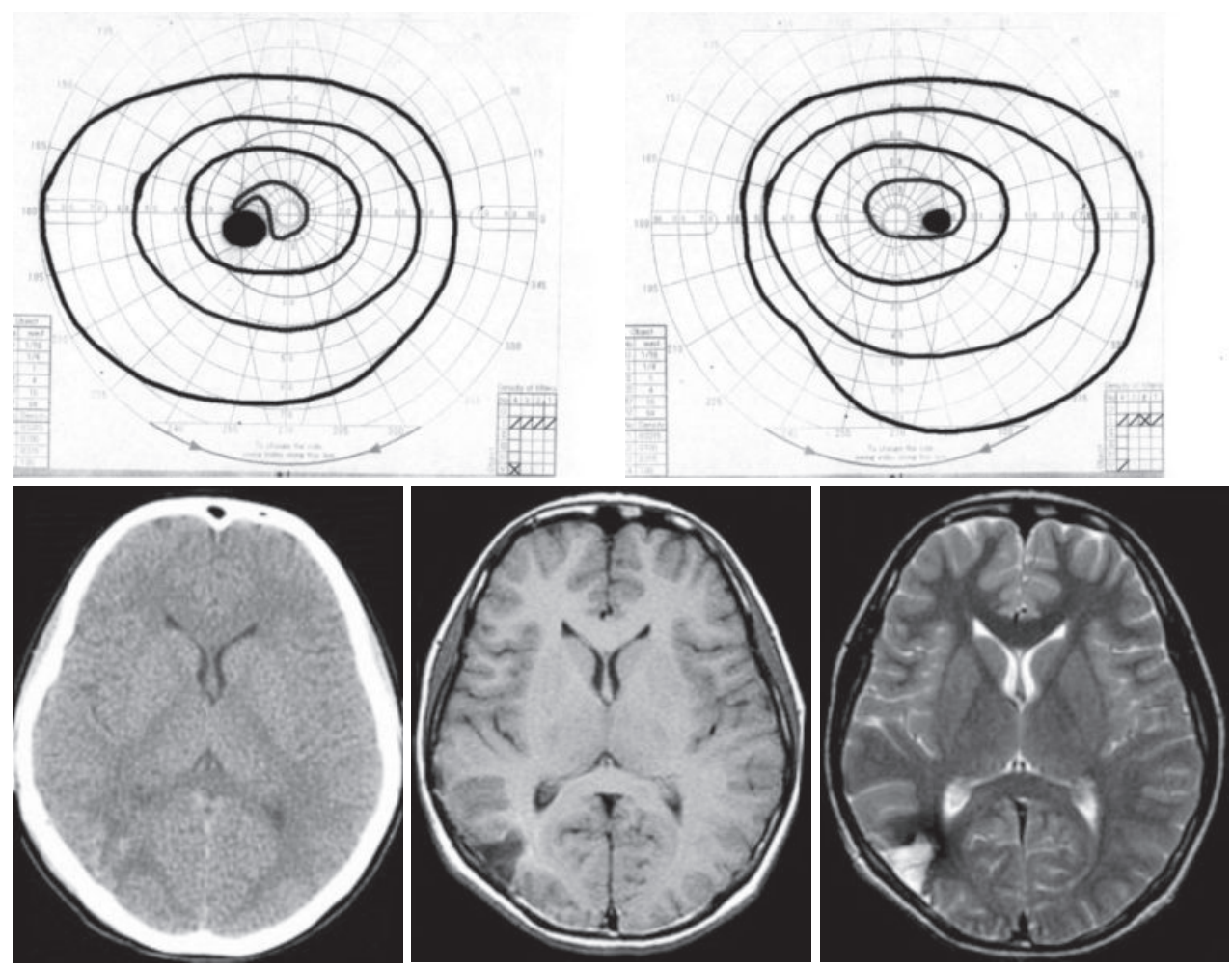

Fig. 10 The postoperative visual fields were intact. A computed tomography scan and magnetic resonance image (T1WI and T2WI) showing disappearance of the angioma.

動麻痖が後遺した 2 例において運動麻痺は $4 / 5$ と軽度で あったが，現在の方法では MEP が消失した場合麻痺の程 度を把握できないという点に注意が必要である。

次に, 上肢 SEP は N20の逆転を用いた運動領野の mappingに有用であった CEA では, 術中の脳虚血を経頭蓋 MEP と同時にモニ夕 リングすることにより double checkできるという点で有 用と思われた。 下肢 SEP は, 両側の前大脳動脈の血流不 全の同定のために用いている. 現段階では, 経頭蓋刺激下 肢 MEP は体動や false positive の問題があり, テント上病 変に対しては確立された方法とは考えていない. 今後は下 肢の皮質直接刺激 $\mathrm{MEP}^{5)}$ も有用となってくるかもしれな い.

次に, VEP の適応は, 脳動脈瘤では, 後大脳動脈瘤や 大型の内頚動脈瘤・前交通動脈瘤など, 視神経から視交叉 近傍の動脈箇などである，前床突起の削除や視神経管の開 放の際に視機能に変化がないことを確認できる点で有用で あったＶVEPにより血流不全を同定できるのは，眼動 脈, 上下垂体動脈, 後大脳動脈であった ${ }^{11)}$ 。また, VEP は視覚路全長にわたる機械的な損傷の同定にも有用で, 大 型動脈瘤で動脈瘤と視神経の剝離を要するような症例, 側 頭葉および後頭葉に存在する AVM や海綿状血管腫がよい
適応となる ${ }^{11)}$.

最後に, $\mathrm{rSO}_{2}$ の適応であるが，これは現段階では $\mathrm{CEA}$ のみである。一般的に, 局所脳内酸素飽和度 $\left(\mathrm{rSO}_{2}\right)$ の相 対值 $20 \%$ 以上の低下あるいは絶対值 $40 \%$ 以下で脳の低酸 素状態と診断する ${ }^{15)}$. NIRS と MEP の関係では, Uchino $ら^{14)}$ は $\mathrm{rSO}_{2}$ が $20 \%$ 低下すると MEP の振幅が低下し始め ると報告している，いまだ症例数が少なくデータの集積が 必要であるが, 今後機器の発展に伴い多チャンネルの術中 モニタリングが可能になれば，さらに有用なものになると 考えている.

\section{結 論}

脳卒中の外科治療においては, 各種モニタリングにより 術中に脳や神経の虚血状態を感知し, 手術に feedbackす ることができる点が有用と思われた。運動領野の mapping には MEP と SEPによる double check が有用であっ た.また, VEPは視覚路の機械的損傷の同定にも有用で あった，CEA では MEP や SEP が安全な血流一時遮断と 内シャント使用の判断に有用であり, $\mathrm{rSO}_{2}$ のモニタリン グも double checkのために有用であった. 


\section{文献}

1）阿部 誠, 佐々木達也, 昆 博之, ほか：経頭蓋刺激運動誘 発電位の刺激間値の術中変動に関する検討。青県病誌 58 : 84-88, 2013

2) Horiuchi K, Suzuki K, Sasaki T, et al: Intraoperative monitoring of blood flow insufficiency during surgery of middle cerebral artery aneurysm. J Neurosurg 103: 275-283, 2005

3）井上瑞穂, 成澤あゆみ, 阿部 誠, ほか：視覚誘発電位モ二 タリング下に摘出した後頭葉海綿状血管腫の 1 例. 青県病誌 57: 102-107, 2012

4）小山新弥, 長南雅志, 昆 博之, ほか：局所酸素飽和度, 運 動誘発電位, 体性感覚誘発電位を用いた䅡動脈内膜剥離術の 術中モニタリング一内シャントの必要性に関連して。脳卒中 の外科 42: 340-346, 2014

5) Maruta $Y$, Fujii M, Imoto H, et al: Intra-operative monitoring of lower extremity motor-evoked potentials by direct cortical stimulation. Clin Neurophysiol 123: 1248-1254, 2012

6) Sasaki $\mathrm{T}$, Kodama N, Matsumoto M, et al: Blood-flow disturbance in perforating arteries attributable to aneurysm surgery. J Neurosurg 107: 60-67, 2007

7) Sasaki T, Itakura T, Suzuki K, et al: Intraoperative monitoring of visual evoked potential: introduction of a clinically useful method. J Neurosurg 112: 273-284, 2010
8）佐々木達也, 鈴木恭一：はじめての上肢 SEP モニタリン グ. 脳外速報 20: 544-551, 2010

9）佐々木達也, 鈴木恭一：はじめての下肢 SEP モニタリン グ. 脳外速報 20: 670-675, 2010

10）佐々木達也, 鈴木恭一：はじめての VEP モニタリング．脳 外速報 20: 1036-1043, 2010

11）佐々木達也, 西嶌美知春: 術中 VEP モニタリングによる視 機能の温存一VEPに変化をきたした手術手技の検討から. No Shinkei Geka 41: 961-976, 2013

12）佐々木達也, 昆 博之, 斉藤敦志, ほか: 脳動脈瘤手術にお ける術中 MEP を用いた穿通枝梗塞回避の現状と限界. 脳卒 中の外科 42: 347-352, 2014

13) Suzuki K, Kodama N, Sasaki T, et al: Intraoperative monitoring of blood flow insufficiency in the anterior choroidal artery during aneurysm surgery. J Neurosurg 98: 507-514, 2003

14) Uchino $H$, Nakamura $T$, Kuroda $S$, et al: Intraoperative dual monitoring during carotid endarterectomy using motor evoked potentials and near-infrared spectroscopy. World Neurosurg 78: 651-657, 2012

15) Yao FS, Tseng CC, Ho CY, et al: Cerebral oxygen desaturation is associated with early postoperative neuropsychological dysfunction in patients undergoing cardiac surgery. $J$ Cardiothorac Vasc Anesth 18: 552-558, 2004 